\title{
Amino Acids Metabolism in the Muscle of Sheep fed with Mitchell Grass Hay Supplemented with Gliricidia sepium
}

\author{
Y. Widiawati ${ }^{1^{*}}$, M. Winugroho ${ }^{1}$ and E. Teleni ${ }^{2}$ \\ IIndonesian Research Institute for Animal Production (IRIAP), \\ Jl. Veteran III, Ciawi, Bogor 16002, Indonesia \\ ${ }^{2}$ Veterinary Science Department, James Cook University, Townsville, Australia
}

\section{ARTICLE INFO}

\section{Article history:}

Received 29 September 2016

Received in revised form 19 November 2017

Accepted 15 February 2018

\section{Keywords:}

Gliricidia sepium

amino acids

protein synthesis

\begin{abstract}
A B S T R A C T
Leaf of Gliricidia sepium contains high amino acid that required for protein synthesis in the muscle. Supplementation of the legume leaves to low quality basal diet would improves amino acids amount to obtain an optimum growth of animal. The aim of experiment was to investigate the effect of Gliricidia sepium leaves supplementation to low quality basal diet on protein synthesis in muscle of animal. Eighteen sheeps were divided into three groups based on live weight $(27.6 \pm 1.72$, $27.1 \pm 2.26$ and $27.5 \pm 1.56 \mathrm{~kg}$ ) of feed treatment, namely Mitchell grass hay (MG), Gliricidia (GS), and hay combined with Gliricidia (MGGS). All the diet was offered with the amount was determined to meet the maintenance metabolizable energy (ME) requirement of the animals. Feed utilization and amino acid metabolism in muscle of sheep was measured with radioactively labeled leucine, water and sodium bicarbonate. Results indicated that sheep in MG group had a negative energy balance, whereas sheep in MGGS group had the highest amount of ME available for growth. The rate of protein synthesis was higher in the MGGS group and tended to take up these amino acids in their hind-limb muscles, while animals in MG and GS groups tended to have net outputs of amino acids from their hind-limb muscles. Animals in the MGGS group synthesised more protein in their muscle than those in the GS and MG groups. It was concluded that the supplementation of Gliricidia at a ratio of 40:60 improved feed utilization of low quality basal diet. The improvement would be manifested in better digestible organic matter intake (DOMI) with subsequent better utilization of amino acids.
\end{abstract}

\section{INTRODUCTION}

Supplementation of low quality basal diet (grass and agricultural by product) by leguminouse leaves (Leucaena keucocephala, Gliricidia sepium and Calliandra callothyrsus, etc) aimed to improve ruminants productivity has been reported [1-4]. This supplementation was effectively increased the nutrient availability for the animals, in particular nitrogen required for optimum rumen microbial activity during rumen digestion of the feed. Improvement on feed intake, nutrient digestibility,

\footnotetext{
*Corresponding author.

E-mail address: yeni_widiawati14@yahoo.com

DOI: https://doi.org/10.17146/aij.2018.528
}

rumen fermentation efficiency and microbial protein as an effect of Leucaena or Gliricidia leaves supplementation has also been studied [5].

Animal's response to increasing nitrogen supply from legume leaves was manifested by improving in live weight gain. The intake and live weight gain of growth of Bali cattle fed with grass were observed when legume leaves was supplemented in the diet [6]. Previous study on the supplementation of Gliricidia leaves on grass basal diet indicated a significant increasing in dietary nitrogen retained in the sheep up to $18.4 \%$ [7]. Dietary nitrogen is one of amino acids source for ruminant. Therefore, increasing in dietary retained nitrogen will be an indication of more supply of 
amino acids needed for protein synthesis. The important of dietary nitrogen for ruminants is not only to supply amino acids, but also as nitrogen sources for microbial protein synthesised in the rumen [8,9]. Rumen microbial protein is also a contributor of amino acids for ruminant animals. Thus information on the amino acids supply from Gliricidia leaves and its role in protein synthsis in the muscle of ruminant animal is required.

Protein as a source of amino acid is the most nutrient required for protein synthesis in the tissue muscle $[10,11]$. It was reported that large retention of nitrogen indicated a better utilization of dietary protein for muscle deposition, which in turn increase live weight gain [12]. Leucine and isoleucine were reported as essential amino acids required for protein synthesis. Among three legumes of Leucaena, Gliricidia and Calliandra, the Gliricidia and Leucaena contain higher amino acids compared to Calliandra leaves [13]. However, Calliandra was reported to contain high tannin as anti-nutritive that reduced the protein utilization by ruminant animals [14]. On the other hand, Gliricidia was reported produces higher leaves biomass per period of production compared to the two other legumes (Leucaena and Calliandra) [15]. Therefore the study was undertaken to determine the role of Gliricidia leaves as amino acids source for protein synthesis in sheep's muscle.

\section{EXPERIMENTAL METHODS}

\section{Animals and feed}

Eighteen sheep, approximately 18 months old, were used in a Randomized Block Design [16]. They were divided into three equal groups, evenly matched for live weight (LW). Each group was allocated at random to the following dietary treatments: Mitchell grass hay (Astrebla lappacea/MG), Gliricidia (Gliricidia sepium/GS), and MG combined with GS (MGGS). The mean \pm SE of initial LW of animals in each treatment group were $27.6 \pm 1.72(\mathrm{MG}) ; 27.1 \pm 2.26(\mathrm{GS})$ and $27.5 \pm 1.56 \mathrm{~kg}$ (MGGS).

The diets offered were designed to meet the Metabolize Energy (ME) for maintenance required by sheep according to National Research Council (NRC) [17]. The amount of Gliricidia leaves offered to animals in MGGS group was $37 \%$ of total daily ration in dry matter (DM) base. This proportion was calculated to result in a nitrogen intake (NI):DOMI ratio of 0.04 [18] for optimum rumen microbial activity in feed digestion. Dry matter offered was $815 \mathrm{~g} /$ day for MG and $578 \mathrm{~g} /$ day for GS, and $254 \mathrm{~g} /$ day of grass hay $+456 \mathrm{~g} /$ day of Gliricidia leaves for MGGS. The ration for each animal was divided into 12 equal portions, where each portion was given at 2-hour intervals from 07:00 AM to 15:00 PM. The balance of the $24 \mathrm{~h}$ ration was given to the animals at 17:00 PM. This feeding regimen was designed to provide a continuous flow of amino acids from the rumen into the duodenum, which should ensure a net amino acid absorption from the intestine [19].

\section{Procedures}

The experiment consisted of a 14-day period of adaptation to feeds and an 11-day of measurement period. The measurements undertaken were feed utilization (intake, digestibillity and $\mathrm{N}$ balance) and the kinetics of urea, amino acid, and $\mathrm{CO}_{2}$. Samples of feed offered, total feed residues and total faeces and urine excreted by the animals were collected each day for 7 days for feed utilization determination.

A set of chronic indwelling catheters was installed in the jugular veins, a femoral artery and a lateral saphenous vein of each sheep following procedur of Anisson [20] for determination of amino acids metabolism in the muscle. The procedure of catheters installation to the animals has been approved (Experimentation Ethics Approval No A635_01).

Infusate used in the experiment were $\mathrm{L}-\left[{ }^{14} \mathrm{C}\right]$ leucine $(13 \mathrm{kBq} / \mathrm{mL})$, tritiated water $\left[{ }^{3} \mathrm{HOH}\right]$ $(925 \mathrm{kBq} / \mathrm{mL}$ and $9.25 \mathrm{kBq} / \mathrm{mL})$, and sodium $\left[{ }^{14} \mathrm{C}\right]$ bicarbonate $\left(\mathrm{NaH}^{14} \mathrm{CO}_{3}\right) \quad(15.98 \mathrm{kBq} / \mathrm{mL})$. The radioactivity of each infusate was determined immediately before and after the relevant infusion period. During the determination of amino acids metabolism, the L-[1- $\left.{ }^{14} \mathrm{C}\right]$ leucine $(0.33 \mu \mathrm{Ci} / \mathrm{mL})$ was infused continuously into the left jugular venous catheter of each experimental animal at the rate of $1 \mathrm{~mL} / \mathrm{min}$ for 5.5 hours. It was assumed that the spesific radioactivity (SRA) of leucine in the blood would start to plateau at two hours after the infusion started. Blood flow measurement was undertaken between the 3rd and 4th hour of $\mathrm{L}-\left[1-{ }^{14} \mathrm{C}\right]$ leucine infusion [20] by using ${ }^{3} \mathrm{HOH}$ $(925 \mathrm{kBq} / \mathrm{mL})$ solution that infused for 60 minutes into the right jugular venous catheter.

Two blood samples $(5 \mathrm{~mL}$ and $10 \mathrm{~mL}$ each) were withdrawn from the femoral artery and lateral saphenous vein of each animal before and during the infusion of the leucine tracer for determination of radioactivity of leucine and $\mathrm{CO}_{2}$. Five sets of three blood samples were withdrawn using syringes, at 20-minute intervals from the femoral artery and 
lateral saphenous vein of each animal for determination of leucine radioactivity and amino acid concentration, determination of $\mathrm{CO}_{2}$ radioactivity and blood gas determination.

The metabolized energy (ME) intake, ME required for maintenance and $\mathrm{ME}$ for growth were calculated based on the following equation [21]:

ME-intake $(M J / d)=[0.15 x(D O M I / D M I) x 100] x D M I$, $M E$-maintenance $(M J / d)=1.2+0.13 \mathrm{LW}$

$M E-\operatorname{growth}(M J / d)=M E-i-M E-m$

\section{Statistical analysis}

All raw data were tabulated using Excel and analysed using IBM SPSS Statistics 20. Data were analyzed using ANOVA for the randomized block design. When significant effects of treatments were observed, differences among mean values were examined using Tukey's test [16].

\section{RESULTS AND DISCUSSION}

\section{Feed utilization and energy balance}

The grass and Gliricidia contain crude protein (5.7\% and $23 \%$ ); gross energy (18 and 17.26 $\mathrm{MJ} / \mathrm{kg} \mathrm{DM}$ ), and NDF (55.3 and $51 \%$ ). Sheep in the MG and GS groups consumed similar amounts of DM but they consumed significantly less DM than the sheep in the MGGS group (Table 1). The apparent DM and organic matter (OM) digestibility values of the MGGS diet were between the values observed for MG and GS diet, with the lowest values recorded for the MG diet. Animals in GS group had the highest $\mathrm{N}$ intake, followed by MGGS and MG groups. About half of $\mathrm{N}$ consumed by animals in GS group was excreted as urinary N. The $\mathrm{N}$ value was significantly higher than those recorded in animals in the MGGS and MG groups. On the other hand, animals in the MG and MGGS groups excreted more than $50 \%$ of their respective dietary $\mathrm{N}$ intake in faeces. The animals fed with MG had a negative $\mathrm{N}$ balance, while those fed with GS and MGGS had positive $\mathrm{N}$ balance values. The amount of $\mathrm{N}$ intake retained in animals in the MGGS group was significantly higher than that in animals in the GS group. Animals fed with MG was lost weight during the observation period, while animals fed with GS and MGGS gained LW. The LW gain was significantly higher in MGGS group. The feed conversion ratio was lower in MGGS than in GS group. The value of NI:DOMI ratio for the MGGS group was between the values recorded for the other two groups; the highest being observed in the GS group.
Table 1. Feed utilization by sheep fed Mitchell grass hay supplemented or not with Gliricidia.

\begin{tabular}{|c|c|c|c|c|}
\hline \multirow{2}{*}{ Variable } & \multicolumn{3}{|c|}{ Treatment } & \multirow[b]{2}{*}{ SE } \\
\hline & MG & GS & MGGS & \\
\hline \multicolumn{5}{|l|}{ Intake $(\mathrm{g} / \mathrm{d})$} \\
\hline DM & $577^{\mathrm{b}}$ & $608^{\mathrm{b}}$ & $746^{\mathrm{a}}$ & 60 \\
\hline $\mathrm{OM}$ & 511 & 569 & 612 & 71 \\
\hline \multicolumn{5}{|l|}{ App. Digestibility (\%) } \\
\hline DM & $44^{\mathrm{c}}$ & $55^{\mathrm{a}}$ & $49^{\mathrm{b}}$ & 1.4 \\
\hline $\mathrm{OM}$ & $52^{\mathrm{c}}$ & $59^{\mathrm{a}}$ & $56^{\mathrm{b}}$ & 0.8 \\
\hline \multicolumn{5}{|l|}{$\mathrm{N}$ balance $(\mathrm{g} / \mathrm{d})$} \\
\hline $\mathrm{N}$ intake & $3.4^{\mathrm{c}}$ & $15.7^{\mathrm{a}}$ & $10^{\mathrm{b}}$ & 0.8 \\
\hline $\mathrm{N}$ faeces & $2.6^{\mathrm{c}}$ & $7.0^{\mathrm{a}}$ & $5.2^{\mathrm{b}}$ & 0.6 \\
\hline $\mathrm{N}$ urine & $0.9^{\mathrm{c}}$ & $7.9^{\mathrm{a}}$ & $2.9^{\mathrm{b}}$ & 0.4 \\
\hline $\mathrm{N}$ retained & $-0.12^{\mathrm{c}}$ & $0.80^{\mathrm{b}}$ & $1.84^{\mathrm{a}}$ & 0.7 \\
\hline$N I: D O M I$ & $0.01^{\mathrm{c}}$ & $0.05^{\mathrm{a}}$ & $0.03^{\mathrm{b}}$ & 0.33 \\
\hline LW gain LWG $(g)$ & $-90^{c}$ & $28^{\mathrm{b}}$ & $80^{\mathrm{a}}$ & 53 \\
\hline FC ratio(gDMI/gLWG) & - & $22^{\mathrm{b}}$ & $9^{\mathrm{a}}$ & 8.9 \\
\hline
\end{tabular}

Within rows, mean with different superscript different significantly App. Digestibility = apparent digestibility; $\mathrm{DM}=$ dry matter; $\mathrm{OM}=$ organic mattter; $\mathrm{N}=$ nitrogen; $\mathrm{NI}=$ nitrogen intake; DOMI = digestible organic matter intake; LW = live weight; Fcratio $=$ Feed convertion ratio; $\mathrm{MG}=$ Mitchel grass; $\mathrm{GS}=$ Gliricidia sepium; MGGS = mitchel grass+Gliricidia sepium.

All animals required similar amounts of ME for maintenance. Animals in the MGGS group had the highest ME intake, while animals in the MG and GS groups consumed similar amounts of ME (Table 2). Sheep fed MG had a negative energy balance, while sheep fed MGGS had the highest amount of ME available for growth.

Table 2. Energy utilization by sheep fed with Mitchell grass hay supplemented with Gliricidia

\begin{tabular}{|c|c|c|c|c|}
\hline \multirow[b]{2}{*}{ Variables } & \multicolumn{3}{|c|}{ Treatments } & \multirow[b]{2}{*}{$\pm \mathbf{S E}$} \\
\hline & MG & GS & MGGS & \\
\hline \multicolumn{5}{|l|}{ Energy balance $(\mathrm{MJ} / \mathrm{d})$} \\
\hline$M E-i^{1}$ & $4.0^{\mathrm{b}}$ & $5.0^{\mathrm{b}}$ & $5.7^{\mathrm{a}}$ & 0.46 \\
\hline $\mathrm{ME}-\mathrm{m}^{2}$ & 4.7 & 4.7 & 4.8 & 0.34 \\
\hline $\mathrm{ME}-\mathrm{g}^{3}$ & $-0.7^{\mathrm{b}}$ & $0.3^{\mathrm{a}}$ & $0.9^{\mathrm{a}}$ & 0.35 \\
\hline ME-retained (\%ME-i) & $0^{\mathrm{c}}$ & $6.0^{\mathrm{b}}$ & $15.8^{\mathrm{a}}$ & 2.24 \\
\hline
\end{tabular}

Within rows, means with different superscript, differ significantly. ME-I = Metabolize energy intake; ME- $\mathrm{m}=$ Metabolize energy maintenance; ME-g = metabolize energy growth

\section{Urea kinetics}

The urea kinetics in sheep fed the experimental feed measured during the experiment is presented in Tabel 3.

Sheep fed with GS had the highest plasma urea concentration, urea entry rate (UER), amount of urea excreted through urine and volume of excreted urine among the treatment groups. The lowest corresponding values were observed in the MG fed animals. The urinary $\mathrm{N}$ present as urea $\mathrm{N}(\%)$ was similar for the GS and MGGS sheep, both values were higher than that observed in the MG fed animals. 
Table 3. Urea kinetics in sheep fed with Mitchell grass hay supplemented with Gliricidia

\begin{tabular}{lcccc}
\hline \multirow{2}{*}{ Variables } & \multicolumn{3}{c}{ Treatments } & \\
\cline { 2 - 4 } & MG & GS & MGGS & \pm SE \\
\hline Plasma urea concentration & $27^{\mathrm{c}}$ & $80^{\mathrm{a}}$ & $55^{\mathrm{b}}$ & 6 \\
$(\mathrm{mg} / 100 \mathrm{~mL})$ & $27^{\mathrm{c}}$ & $82^{\mathrm{a}}$ & $58^{\mathrm{b}}$ & 7 \\
Urea entry rate $(\mathrm{UER})(\mathrm{g} / \mathrm{d})$ & $0.8^{\mathrm{b}}$ & $10.3^{\mathrm{a}}$ & $4.3^{\mathrm{b}}$ & 4.8 \\
Urinary urea $(\mathrm{g} / \mathrm{d})$ & $42^{\mathrm{b}}$ & $61^{\mathrm{a}}$ & $70^{\mathrm{a}}$ & 8 \\
Urinary N as urea-N $(\%)$ & $928^{\mathrm{b}}$ & $1645^{\mathrm{a}}$ & $953^{\mathrm{b}}$ & 402 \\
Urine output $(\mathrm{mL} / \mathrm{d})$ & &
\end{tabular}

Within rows, values with different superscript differ significantly UER was estimated using: $\mathrm{Y}=0.7932 \mathrm{X}+16.027$,

$\mathrm{Y}=$ urea entry rate $(\mathrm{g} / \mathrm{d}) ; \mathrm{X}=$ plasma urea concentration $(\mathrm{mg} / 100 \mathrm{~mL})$

\section{Protein synthesis}

Based on the kinetics of ${ }^{3} \mathrm{HOH}$ solution that was infused during the 60 minutes period into the right jugular venous of the sheep, the blood flow can be determined. Thus, with the combination of $\mathrm{L}-\left[1-{ }^{14} \mathrm{C}\right]$ leucine infusion, the metabolism of leucine in the whole body of the sheep can be calculated.

Dietary treatments significantly influenced leucine entry rate (LER) (Table 4). The LER in MGGS groups was the highest compared to other groups. It was not significantly different with the LER observed in the GS group, but was significantly different with the LER in MG group.

Dietary treatments significantly affected the proportion of decarboxylated leucine. Animals fed with GS had the highest percentage of decarboxylated leucine. This also was shown by the amount of $\mathrm{CO}_{2}$ produced from leucine. However, the percentage of decarboxylation and $\mathrm{CO}_{2}$ amount produced from leucine in GS group were not different with the values observed in MGGS group. These values were significantly higher than in MG animals. The estimated mean rate of protein synthesis was higher in MGGS group and significantly higher than that observed in $\mathrm{MG}$ group, but did not differ significantly from GS group.

Table 4. Leucine metabolism in the whole body of sheep fed with Mitchell grass hay supplemented with Gliricidia

\begin{tabular}{lcccc}
\hline \multicolumn{5}{c}{ Treatments } \\
\hline Variables & MG & GS & MGGS & \pm SE \\
\hline Whole body & & & & \\
LER $(\mathrm{mmol} / \mathrm{h})$ & $13.6^{\mathrm{b}}$ & $17.6^{\mathrm{ab}}$ & $20.4^{\mathrm{a}}$ & 2.3 \\
$\mathrm{CO}_{2}$ leucine $(\mathrm{mmol} / \mathrm{h})$ & $0.4^{\mathrm{b}}$ & $0.6^{\mathrm{a}}$ & $0.6^{\mathrm{ab}}$ & 0.1 \\
Leucine DO $(\%)^{\text {Protein synthesised }}{ }^{2)}(\mathrm{g} / \mathrm{d})$ & $9^{\mathrm{b}}$ & $42^{\mathrm{a}}$ & $24^{\mathrm{ab}}$ & 11 \\
\hline
\end{tabular}

Within rows, values with different superscripts differ significantly LER = Leucine entry rate; Leucine DO = Leucine decarboxylase

1) It was assumed that empirical factor for respiratory output of mature sheep is $0.235 \mathrm{mmol} \mathrm{CO} 2 / \mathrm{min} / \mathrm{kg} \mathrm{LW}$.

2) It was assumed that leucine content in sheep muscle is $127.6 \mathrm{mmol} / \mathrm{kg}$ muscle [18].
The dietary treatments did not have a significant effect on the extraction of leucine by the hind-limb muscle (Table 5). However, treatments did have a significant effect on the proportion of leucine taken up by muscle that was catabolised. The animals in GS group had the highest proportion of catabolised leucine while those in MG group had the lowest. The contribution of leucine to muscle $\mathrm{CO}_{2}$, likewise, was significantly affected by the dietary treatments and was highest in GS group and lowest in MG group. The amounts of leucine involved in muscle protein synthesis were higher in GS and MGGS groups than in MG group. Animals in MGGS group synthesized more protein in their muscle than those animals in GS and MG groups. Dietary treatments had no significant effect on arterial concentrations of essential amino acid (Table 5), although the concentrations tended to be higher in GS group than MG and MGGS groups.

Table 5. Leucine kinetics and protein synthesis in total muscle of sheep fed Mitchell grass hay supplemented or not with Gliricidia

\begin{tabular}{|c|c|c|c|c|}
\hline \multirow[b]{2}{*}{ Variables } & \multicolumn{3}{|c|}{ Treatments } & \multirow[b]{2}{*}{$\pm \mathbf{S E}$} \\
\hline & MG & GS & MGGS & \\
\hline \multicolumn{5}{|l|}{ Hind-limb muscle: } \\
\hline Leucine fraction extracted $(\%)$ & 19 & 20 & 17 & 4 \\
\hline True leucine extracted $(\mu \mathrm{M})$ & 28 & 34 & 29 & 7 \\
\hline Leucine catabolism (\% of uptake) & $17^{\mathrm{c}}$ & $58^{\mathrm{a}}$ & $36^{\mathrm{b}}$ & 8 \\
\hline leucine to muscle $\mathrm{CO}_{2}(\%)$ & $0.1^{\mathrm{b}}$ & $0.4^{\mathrm{a}}$ & $0.3^{\mathrm{b}}$ & 0.13 \\
\hline $\begin{array}{l}\text { Leucine for protein synthesis }{ }^{1)} \\
(\mu \mathrm{mole} / \mathrm{h} / \mathrm{kg} \text { muscle })\end{array}$ & $164^{\mathrm{b}}$ & $328^{\mathrm{a}}$ & $310^{\mathrm{a}}$ & 79 \\
\hline \multicolumn{5}{|l|}{ Total muscle: } \\
\hline $\mathrm{CO}_{2}$ from leucine $(\mathrm{mmole} / \mathrm{h})$ & $0.04^{\mathrm{c}}$ & $0.25^{\mathrm{a}}$ & $0.25^{\mathrm{b}}$ & 0.06 \\
\hline Protein synthesized ${ }^{2)}(\mathrm{g} / \mathrm{d})$ & $33^{\mathrm{b}}$ & $34^{\mathrm{b}}$ & $63^{\mathrm{a}}$ & 11 \\
\hline $\begin{array}{l}\text { Protein synthesis (muscle/whole } \\
\text { body, } \% \text { ) }\end{array}$ & 9 & 7 & 11 & \\
\hline
\end{tabular}

Within rows, values with different superscripts differ significantly

1) It was assumed that muscle mass is $25 \%$ of $\mathrm{LW}$.

2) With the assumption that protein fraction in muscle of sheep six months of age was 0.16 [18]

Data on the arterial concentration of Isoleucine and Leucine in sheep fed experimental feed measured during the experiment is presented in Table 6.

Table 6. Concentrations of leucine and isoleucine in arterial sheep $(\mu \mathrm{M})$ fed with Mitchell grass hay supplemented with Gliricidia

\begin{tabular}{lcccc}
\hline & \multicolumn{3}{c}{ Treatments } & \\
\cline { 2 - 4 } Variables & MG & GS & MG & \pm SE \\
Arterial concentration $(\boldsymbol{u} M)$ & & & GS & \\
Isoleucine & 79 & 93 & 84 & 4 \\
Leucine & 150 & 192 & 163 & 8 \\
\hline
\end{tabular}

The amount of grass fed to the animals were calculated to provide $4.8 \mathrm{MJ} /$ day of ME required for maintenance of sheep. However, animals in the MG 
group did not eat all of the diet offered. Consequently, the animal in this group was in negative energy balance (Table 2) and lost of their LW (Table 1). Animal in GS and MGGS groups consumed slightly higher ME (6\% and $19 \%$ respectively) than other group. As a consequence, both groups had some ME available for growth (Table 2) and thus gained LW. These are consistent with the observation that both groups also had positive $\mathrm{N}$ balance (Table 1). It is clear that the loss weight of animals in MG group was due to the low DMI and DM digestibility of the grass (44\%; Table 1) as well as low protein content of $\mathrm{MG}$ $(5.7 \%)$. The result was similar with the other report that showed low digestibility (46\%) of the grass with low CP content (5.6\%) [22]. The addition of GS to MG in MGGS group increased intake and digestibility by $29 \%$ and $11 \%$, respectively. Such improvements are in agreement with other research that found that the addition of GS to Buffel grass improved digestibility [23].

The most probably reason of DMI and digestibility improvement in MGGS group was due to the shift in NI:DOMI ratio of 0.01 in MG group to 0.03 in MGGS group when GS was supplemented. The finding was coherent with the study indicated that rumen microbial activity improved when grass supplemented with GS [22]. Moreover, suplementation of Gliricidia improved digestibility of Buffel grass by hairly sheep [23]. The improvement in feed efficiency in MGGS group was shown by the lower feed conversion ratio (Table 1). The MGGS group consumed $9 \mathrm{~g}$ of DM/unit of LWG compared with $22 \mathrm{~g}$ DM/unit LWG consumed by GS group. This improvement was most likely due to better nutrient balance.

Negative $\mathrm{N}$ balance observed in MG group was consistent with the value of amino acid outflow from hind-limb muscle (Table 5). Urea concentration in plasma was positively associated with $\mathrm{N}$ intake, with reflects the catabolism of amino acids, both within the rumen and at the body tissue level $(\mathrm{Y}=4.01 \mathrm{X}+15.045$, $\mathrm{R}^{2}=0.8049$; where $\mathrm{Y}$ is the plasma urea concentration and $\mathrm{X}$ is the nitrogen intake). Differences in the rates of urine secreted by the sheep fed with the different diets probably were due largely to differences in urea concentration in the plasma. The large urine output in GS group reflected the increased osmotic load in blood of animals caused by high urea concentration in plasma (Table 3).

The increasing LER in MG group, through GS to the MGGS group, most probably reflected the increasing amounts of leucine (and other amino acids) absorbed from the alimentary tract of the animals in the respective groups (Table 5). It is interesting that although the GS group consumed highest amount of $\mathrm{N}$ (Table 1), the LER for GS and MGGS groups was similar althought the MGGS group consumed less N. It might caused by more balanced NI:DOMI ratio in MGGS, where there was a greater amount of microbial amino acids available for absorption from the small intestine. The apparent increase in LER in GS group would be due to high amount of leucine supplied by Gliricidia (Table 5), as also reported that Gliricidia is one of legumes leaves that contains high leucine and isoleucine [13].

There was a positive relationship between $\mathrm{CP}$ intake and plasma concentration of essential amino acids. This again lends further support to the suggestion that there was increased flow of amino acids from the intestine to the bloodstream of animals with increased $\mathrm{N}$ intake. The concentration of leucine in plasma of MGGS group appear to be lower than that in GS group, although the LER in MGGS group was higher than that in GS group. A high LER would reflect a high utilization rate of leucine, it might be suggested that the apparently lower plasma concentration of leucine in the MGGS group reflected the higher utilization rate of the amino acid in protein synthesis in these animals.

Although higher proportions of the leucine taken up by the hind-limb muscle of animals in GS and MGGS groups that were catabolised, the amounts of amino acids available in hind limb for protein synthesis was higher than that in hind limb of the MG group when blood flow rates across the hind-limb muscle beds (Table 5) are taken into account.

No significant dietary treatment effects were observed on the A-V concentration difference of leucine and isoleucine across the hind-limb muscles (Table 5 and 6). This suggests that probably, the dietary treatments did not affect the transporters of the two amino acids into muscle cells of the animals under observation. Overall, the A-V concentration difference of amino acids across the hind-limb muscles tended to be generally positive in the MGGS group and generally negative in the MG and GS groups (Table 5). It is most likely that the positive $\mathrm{A}-\mathrm{V}$ concentration difference of leucine and isoleucine (Table 5 and 6) in hind-limb muscles of MGGS sheep indicate significant increase in the rate of protein synthesis and net protein deposition in the muscles. This is consistent with the result of $\mathrm{N}$ retained (Table 1). The finding of study also consitent with the report that the amount of nitrogen retained would reflect the amount of protein synthesised in muscle [12].

\section{CONCLUSION}

Supplementation of Gliricidia on Mitchell grass hay increased dietary retained energy (18.9\% 
of energy intake) and protein synthesis due to increasing on supply of amino acids from Gliricidia as well as balance of nitrogen and energy availability as indicated by ratio of N:DOMI (0.04). These results was supported by significantly higher weight gain of the animals after supplementation of Gliricidia leaves.

\section{ACKNOWLEDGMENT}

Authors thank to Australian Centre for International Agricultural Research (ACIAR) for their financial support during the experiment undertaken.

\section{REFERENCES}

1. B.O. Oduguwa, A.O. Oni and O.M. Arigbede, Trop. Anim. Health Prod. 45 (2013) 1363. DOI: 10.1007/s11250-013-0370-y

2. T. Panjaitan, M. Fauzan and Dahlanuddin et al., Tropical Grasslands-Forrajes Tropicales 2 (2014) 116. DOI: 10.17138/TGFT(2)116-118

3. S. Gunasekaran, K. Viswanathan and C. Bandeswaran, International Journal of Science Environment and Technology $\mathbf{3}$ (2014) 1767.

4. N. Hilmiati, Sutartha and T. Panjaitan, International Journal of Sustainable Development 09 ( 2016) 47.

5. M. Wanapat, K. Sungchhang and P. Sineenart, Journal of Animal Science and Biotechnology 4 (2013) 32. https://doi.org/10.1186/20491891-4-32

6. Dahlanuddin, O. Yanuarianto and D.P. Poppi, Animal Production Science 54 (2013) 915.

7. Y. Widiawati, E. Teleni and Suharyono, Atom Indonesia 40 (2014) 121.

8. M.A. Brooks, R.M. Harvey and N.F. Johnson, Journal of Animal Science 90 (2012) 4985.

9. J.N. Kim, E.D. Henriksen and I.K. Cann, Appl Applied and Environmental Microbiology 80 (2014) 3095.

http://www.springerplus.com/content/2/ 1/483.
10. S. Francisco, D. Pacheco and H. Blair, Springplus. 2 (2013) 438.

11. Guoyao Wu, W.B. Fuller and Zhaolai Dai, Annual Review of Animal Biosciences 2 (2014) 569.

12. E.M. Alves, D.R. Magalhães and M.A. Freitas, Acta Scientiarum Animal Science $\mathbf{3 6}$ (2014) 55 .

13. P.A. Aye and M.K. Adegun, Biology Journal of North America 4 (2013) 71.

14. S.J. Bunglavan and N. Dutta, Journal of Livestock Science 4 (2013) 67.

15. Steven Franzel, Sammy Carsan and Ben Lukuyu, Current Opinion in Environmental Sustainability 6 (2014) 98.

16. W.W. Daniel, Biostatistics: A Foundation Analysis in the Health Science, $5^{\text {th }}$ ed., John Wiley and Sons. Inc, USA (1991) 207.

17. Anonymous, Nutrient Requirements of Small Ruminants: Sheep, Goats, Cervids, and New World Camelids, Animal Nutrition Series, National Research Council (2007) 07.

18. T.J. Hackmann and J.L. Firkins, Front Microbiology 15 (2015) 465.

19. I.D. Hume, D.R. Jacobson and J.R. Mitchell, Journal of Nutrition 102 (1972) 495.

20. E. Teleni and E.F. Annison, Australian Journal of Biology Science 39 (1986) 271. DOI.org/10.1071/BI9860271

21. Anonymous, Energy Allowances and Feeding Systems for Ruminants, Great Britain, Department of Agriculture and Fisheries for Scotland, Northern Ireland, Department of Agriculture, London (1975) 15.

22. A.T.W. Raharjo, W. Suryapratama and T. Widyastuti, Journal of Animal Science 1 (2013) 796. ( In Indonesian)

23. J.N. Avilés-Nieto, J.L. Valle-Cerdán and Castrejón-Pineda, Tropical Animal Health and Production 45 (2013) 1357. 